T. Obelets,

$P h D$ in Economics, senior lecturer,

National Technical University of Ukraine "Igor Sikorsky Kyiv Polytechnic Institute"

ORCID ID: 0000-0002-1553-5150

DOI: $10.32702 / 2306-6806.2020 .3 .129$

\title{
MODERN PRACTICE OF IDENTIFYING AND MEASURING THE INFORMAL ECONOMY
}

\author{
Т. В. Обелець, \\ к. е. н., старший викцадач, \\ Національний технічний університет України "Київський політехнічний інститут імені Ігоря Сікорського"
}

\section{СУЧАСНА ПРАКТИКА ВИЗНАЧЕННЯ ТА ВИМІРЮВАННЯ НЕФОРМААЬНОЇ ЕКОНОМІКИ}

The analytical assessment of the consequences of system transformations and the development of effective economic policies stimulates the emergence of new variants of the theory of convergence of socio-economic systems. In connection with this, the importance of clarifying the general theoretical issues and considering the problems associated with new socio-economic trends, taking into account the peculiarities of development of different countries. The main directions of modern economic thought show the continuity of the improvement of well-known scientific views and the emergence of new scientific approaches that are in line with the needs of economic reality.

The article attempts to comprehend the modern conceptualapproach to the definition of an informal economy and to measure its scale in countries that are at different stages of economic development. Interest in the informal sector of the economy exists throughout the world. This is due to the fact that, contrary to the forecasts, the informal economy not only persists in low-income countries, but also develops in new forms in developed countries. In addition, modern scholars recognize that the informal economy is inextricably linked to the formal economy and contributes to the economy as a whole. The paper focuses on the possibilities of combining the conceptual and methodological framework used to measure employment in the informal sector and informal employment in developing countries and in developed countries. In addition, the article presents the tendencies of development and the profile of Ukrainian in formal employment against the backdrop of contemporary world tendencies. The reduction of informal employment in Ukraine and its legalization requires, first of all, the implementation of anti-crisis employment policy measures. These measures require a scientifically sound integrated national employment promotion program aimed at ensuring a balanced supply and demand for labor based on productive employment. The practical value of scientific results is to provide an effective tool for analysing informal employment in countries with different income levels. This will allow for an effective economic policy aimed at minimizing possible social risks.

Необхідність аналітичної оцінки наслідків Системних трансформацій та вироблення дієвої економічної політики стимулюють виникнення нових варіантів теорії конвергенції соціально-економічних систем. Узв'язкУ з цим зростає значення з'ясування загальнотеоретичних питань і розглядУ Проблем, пов'язаних із новими соціально-економічними тенденціями з урахуванням особливостей розвитку різних країн. Основні напрями сучасної економічної думки показують безперервність вдосконалення відомих наукових Поглядів і ПоявУ нових наукових підходів, співзвучних потребам економічної дійсності.

У статті обгрунтовано сучасний концептуальний підхіА до визначення неформальної економіки та вимірювання їі масштабів у країнах, що знаходяться на різних етапах економічного розвитку. Інтерес, $о$ неформального сектору економіки існує у всьому світі. Це пояснюється тим фактом, що всупереч прогнозам неформальна економіка не тільки зберігається у країнах із низьким рівнем доходу, але також розвивається в нових формах у розвинених країнах. Ао того ж сучасні науковці визнають, що неформальна економіка нерозривно пов'язана з формальною економікою і вносить Свій вкАад У економіку загалом. У роботі зосереджено увагу на можливостях поєднання концептуальної і методичної бази, яка використовується дАя вимірювання зайнятості в неформальному секторі та неформальної зайнятості в країнах, що розвиваються, і у розвинених країнах. Крім того, в Статті представлено тенденції розвитку і профіль української неформальної зайнятості на фоні сучасних світових тенденцій. Скорочення нефор- 
мальної зайнятості в Україні та ї̈ легалізація потребує, передусім, реалізації заходів політики зайнятості, що мають антикризову спрямованість. Ці заходи потребують науково обгрунтованої комплексної національної програми сприяння зайнятості, спрямованої на забезпечення збалансованості пропозиції та попиту робочої Сили на основі продуктивної зайнятості. Практичне значення наукових результатів полягає Упредставленні дієвого інструментарію, дя аналізу неформальної зайнятості в країнах із різним рівнем доходів. Цедозволить проводити ефективну економічну політику, спрямовануна мінімізацію можливих соціальних ризиків.

Key words: social and labour relations, informal employment, informal economy, brightening of income.

Ключові слова: сочіально-трудові відносини, неформальна зайнятість, неформальна економіка, детінізачія доходib.

\section{INTRODUCTION}

Creation in Ukraine of the socially oriented labour relations in the conditions of strengthening of a role of globalization and the international competition, on the one hand, and a deformalization of the social and labour relations, deepening of inequality and a shadowing of income of the population, on the other hand, demands strategic approach to formation and effective use of labour potential. The shadowing of national economy at the present stage makes impossible acceleration of economic reforms, growth of social standards of life of the population and integration into the European community. High level of a shadowing of economy is a consequence of low legal and tax culture, reflection of weakness of social and economic institutes and is considered as threat to the vital national interests. One of the biggest obstacles in a way of formation of effective model of the social and labour relations and stable economic development in our country is the shadowing of income that is a consequence of distribution of informal employment and activity in the informal sector of economy. A labour market brightening is important among relevant problems of economic development. Now the sharpness of a problem of legalization of shadow income is caused by scales of informal employment and risks, which accompany her uses.

The rationale for the theoretical foundations of the functioning of the informal economy and the use of informal employment were at the center of attention of the world scientific community. Foreign researchers M. Armstrong, E. Giddens, V. Gimpelson, R. Gussman, R. Kapelyushnikov, M. Castells, A. Porthes, E. Feig, E. Hoffman, L. Chizhova analysed informal employment and its constituent elements. A significant contribution to the development of theoretical, methodological and applied aspects of this problem was made by such Ukrainian scientists as A. Amosh, S. Bandur, A. Grishnova, L. Emelianenko, E. Libanova, A. Novikova, I. Petrova, L. Tkachenko, L. Shaulskaya and others. However, modern scientists have not yet developed an effective tool and comparable data sets for analysing informal employment in countries with different levels of income. There is also a growing recognition that supporting the working poor people in the informal economy is one of

Table 1. Conceptual matrix for the definition of informal employment

\begin{tabular}{|c|c|c|c|c|c|c|c|c|c|}
\hline \multirow{3}{*}{ Production units by type } & \multicolumn{9}{|c|}{ Work on the status of employment } \\
\hline & \multicolumn{2}{|c|}{ Self-employed } & \multicolumn{2}{|c|}{ Employers } & \multirow{2}{*}{$\begin{array}{c}\begin{array}{c}\text { Family } \\
\text { Workers }\end{array} \\
\text { 范 } \\
\stackrel{0}{0} \\
\Xi\end{array}$} & \multicolumn{2}{|c|}{ Hired workers } & \multicolumn{2}{|c|}{$\begin{array}{l}\text { Members of } \\
\text { producer } \\
\text { cooperatives }\end{array}$} \\
\hline & 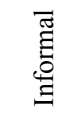 & $\begin{array}{l}\overline{\widetilde{J}} \\
\text { E् } \\
\text { I }\end{array}$ & 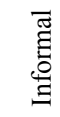 & $\begin{array}{l}\bar{\Xi} \\
\text { Ẽ } \\
\text { II }\end{array}$ & & 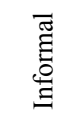 & בే & 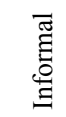 & $\begin{array}{l}\text { चี } \\
\text { : } \\
\text { I }\end{array}$ \\
\hline $\begin{array}{l}\text { Enterprises of the formal } \\
\text { sector }\end{array}$ & & & & & 1 & 2 & & & \\
\hline $\begin{array}{l}\text { Enterprises of the informal } \\
\text { sector }\end{array}$ & 3 & & 4 & & 5 & 6 & 7 & 8 & \\
\hline Households & 9 & & & & & 10 & & & \\
\hline
\end{tabular}

the key ways to reduce poverty and inequality. Since women tend to be concentrated in more unstable forms of informal employment, support for working poor women in the informal sector of the economy is one of the key ways to reduce poverty and gender inequality.

\section{PURPOSE OF THE ARTICLE}

The renewal of interest to the informal economy is accompanied by the need to provide qualitative statistical assessments of this phenomenon. At the heart of this article, in response to this call, several interrelated assumptions are set out. First, there is some statistical information on measuring the extent of informal employment in developing countries, where modern industrial workers have never been a significant part of the labour force. Secondly, more and more developing countries are trying to use the recommendations of international organizations on official statistical definitions. This makes it possible to operate with comparable sets of data that are extremely necessary for conducting research and targeted policies. Third, the conceptual and methodological framework used to measure informal employment in developing countries can and should be applied in developed countries where modern industrial workers are increasingly deformed, and in some countries where self-employment is actively increasing. In addition, the article presents the development tendencies and the profile of Ukrainian informal employment against the background of modern world trends.

\section{STATEMENT OF THE MAIN MATERIAL}

The concept of "informal sector" and "informal employment" are relatively new in the field of statistics. In 1993, the International Conference of Labour Statisticians (ICLS) adopted the international statistical definition of the "informal sector", which was subsequently included in the revised international system of national accounts of 1993 $[13$, p. 138]. In order to fit into the systems of national accounts and ensure a separate accounting of gross domestic product (GDP) in the informal sector, the definition was based on the characteristics of production units or enterprises, rather than labour relations. The "informal sector" refers to employment and production taking place in unincorporated (where at least some goods or services are produced for sale or exchange), small (where fewer than five employees work) or unregistered according to the current legislation enterprises [15, p. 67].

Ten years later, in 2003, following the 2002 International Labour Conference Resolution on "Decent Work and the Informal Economy", the 17 th International Conference of Labour Statisticians discussed conceptual changes in the measure- 
Table 2. Employment in the informal sector and informal employment in countries in terms of income and in Ukraine according to the latest available data 2004/2016

\begin{tabular}{|l|l|l|l|l|l|l|}
\hline \multirow{2}{*}{$\begin{array}{c}\text { Countries by income } \\
\text { level * }\end{array}$} & \multicolumn{2}{|c|}{$\begin{array}{c}\text { Informal employment, } \\
\text { \% Non-agricultural } \\
\text { employment }\end{array}$} & \multicolumn{2}{c|}{$\begin{array}{c}\text { Employment in the } \\
\text { informal sector, } \\
\text { \% Non-agricultural } \\
\text { employment }\end{array}$} \\
\cline { 2 - 8 } & Women & Men & Total & Women & Men & Total \\
\hline Low & 80,8 & 67,0 & 79,1 & 76,9 & 56,8 & 66,6 \\
\hline Below the average & 55,2 & 56,1 & 55,5 & 56,8 & 53,0 & 53,9 \\
\hline Above average & 38,7 & 39,0 & 40,8 & 41,5 & 35,0 & 37,5 \\
\hline Ukraine** & 13,5 & 21,6 & 17,6 & $\ldots$ & $\ldots$ & $\ldots$ \\
\hline
\end{tabular}

High-income countries are not represented

* Ukraine is included in the group of countries with lower than average income.

ment of the informal economy: from working in the informal sector to informal employment and expanded the concept of "informal employment" [16, p. 120]. Total employment was distributed in terms of jobs as a production unit (formal sector enterprises, informal sector enterprises, households); by status of employment (self-employed without employees, employers, family workers, members of production cooperatives) and formal or informal character work (Table $1),[20]$.

Thus, according to the methodology of the International Labour Organization, informal employment is indicated in the matrix by cells $1-6$ and $8-10$, employment in the informal sector by cells 3-8, and informal employment outside the informal sector is outlined by cells 1, 2, 9 and 10. Informal employment refers to all labour agreements that leave workers without social protection as part of their employment, be it economic units, or they work or do not work in formal enterprises, informal enterprises or in households.

Thus, according to international standards, when defining and assessing informal employment, it includes [16, p. 125]:

- self-employed persons working at their own expense and at their own enterprise of the informal sector (the 3rd cell);

- employers who work in their own informal sector enterprises (the 4 th cell);

- family workers employed without a contract of employment and do not have legal or social protection, regardless of whether they work in factories in the real economy or in the informal sector (cells 1 and 5); cell);

- members of informal production cooperatives (8th

- hired workers who occupy informal jobs in real economy enterprises, informal sector enterprises or paid workers employed in households (2, 6 and 10 cells);

- hired workers working in informal enterprises, but have formal jobs, for example, when businesses are defined as informal, using size as the sole criterion (the 7th cell);

- persons working at their own expense and engaged in the production of goods exclusively for their own final consumption by their household (the 9 th cell).

The components of the informal economy can be further classified by categories of the International Classification of the Status of Employee Employment. Within this framework, developed by R. Goossman, certain groups of workers employed in the informal sector and in informal employment outside the informal sector (including rare cases when workers are formally employed in the informal sector) are classified as follows.

Informal employment in the informal sector consists of the following groups:

- self-employed workers in their informal enterprises;

- employers of informal enterprises;

- workers in informal enterprises;

- unpaid family workers employed by informal enterprises;

— members of informal producer cooperatives;
Informal employment outside the informal sector includes:

- employees of official enterprises (including state enterprises, the public sector, private companies and nonprofit organizations) that are not covered by social protection, national labour laws, or the right to receive certain assistance at the workplace, such as annual paid leave or sick leave;

- workers in households (for example, paid workers employed as domestic workers) who are not covered by social protection, national labour legislation, or the right to receive certain assistance at the workplace, such as annual paid leave or sick leave;

- unpaid family workers employed in official enterprises.

Summarizing the terminology, there are three related statistical definitions based on the ICLS resolutions. "Informal sector" refers to unincorporated enterprises, which can also be registered and / or small. "Informal employment" refers to employment without social protection when working within and outside the informal sector. "Informal economy" refers to all informal production units or enterprises, as well as workers working in formal enterprises, but have informal jobs. Together, the workers listed in these categories form a significant stratum of labour, both nationally and globally.

The informal sector is an indispensable attribute of any economy. The informal sector, as a rule, is extremely heterogeneous in its composition and performs various functions, including ensuring the simple survival of people, on the one hand, and the development of entrepreneurship on the other. The increase in the number of countries collecting data on informal employment, both inside and outside the informal sector, and improving the quality of these data, provides an opportunity to form a statistical picture of the informal economy in the world. In countries with a higher level of economic development, the share of employed in the informal sector is less than in the underdeveloped economies (Table 2), [18]. Transition economies as a whole occupy an intermediate position in the informal sector. For example, informal employment accounts for more than half of nonagricultural employment in most developing regions of the world - in particular $82 \%$ in South Asia, $66 \%$ in sub-Saharan Africa, $65 \%$ in East and South-East Asia and $51 \%$ in Latin America. Informal employment in the Middle East and North Africa accounts for $45 \%$ of non-agricultural employment. The lowest level of informal employment - 10\% - in Eastern Europe and Central Asia.

Table 2 gives estimates of employment in the informal sector and informal employment as a share of total nonagricultural employment. Distribution of employment in the informal sector occurs according to the same patterns as the distribution of precarious work: its high level in lowincome countries. In middle-income groups, the share of informal employment is approximately the same for men and women: in countries with incomes above the average, $39.0 \%$ of men and $38.7 \%$ of women work informally, in countries with below-average income of $56.1 \%$ and $55.2 \%$ per cent, respectively.

In countries of one of the three groups of regions, gender differences are clearly delineated, the share of informal employment relative to total non-agricultural employment is higher for women. In poor countries informal employment is more accessible source of non-agricultural employment for women, the level of informal employment among them is $80.8 \%$, while for men this figure is much lower $-67.0 \%$. Women are generally more likely to be employed as unofficial paid domestic workers (informal workers in households), and, to a lesser extent, unpaid family workers at formal enterprises.

The risk of working in the informal sector is higher for women than for men in countries with varying degrees of income. Ukraine is in the group of countries with lower than average income and among these countries has relatively 
low levels of informal employment. Significantly higher risk of informal employment for Ukrainian men, but it should be borne in mind that in Table 1 only non-agricultural employment is represented. In our economy, according to the State Statistical Service of Ukraine for 2016 , more than $40 \%$ of the employed worked informally in agriculture, a significant part of informal employment was in wholesale and retail trade, repair of motor vehicles and motorcycles $(20.9 \%)$, industry $(6,1 \%)$ and construction $(15.5 \%)$, which is traditionally male economic activities.

Estimates of the scale of the informal economy by group of countries provide an overall

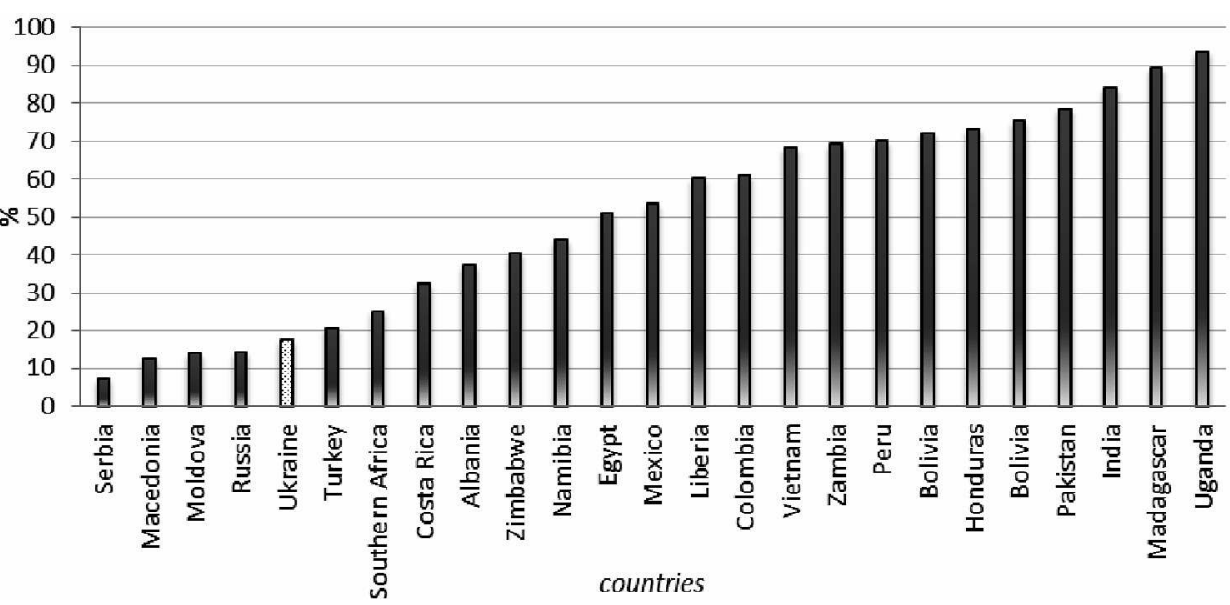
picture, but hide the diversity that exists in the regions. Informal employment, for example, was estimated at 79.1 per cent of non-agricultural employment in low-income countries, but this percentage varies from 60.1 per cent in Liberia to 93.5 per cent in Uganda. Similarly, in countries with incomes below the average, the aggregate indicator is $55.5 \%$, while the share of informal employment in the Republic of Moldova is $14.0 \%$ of non-agricultural employment, in Ukraine $17.6 \%$, and in Pakistan $78.4 \%$. In countries with higher than average income, the variation in informal

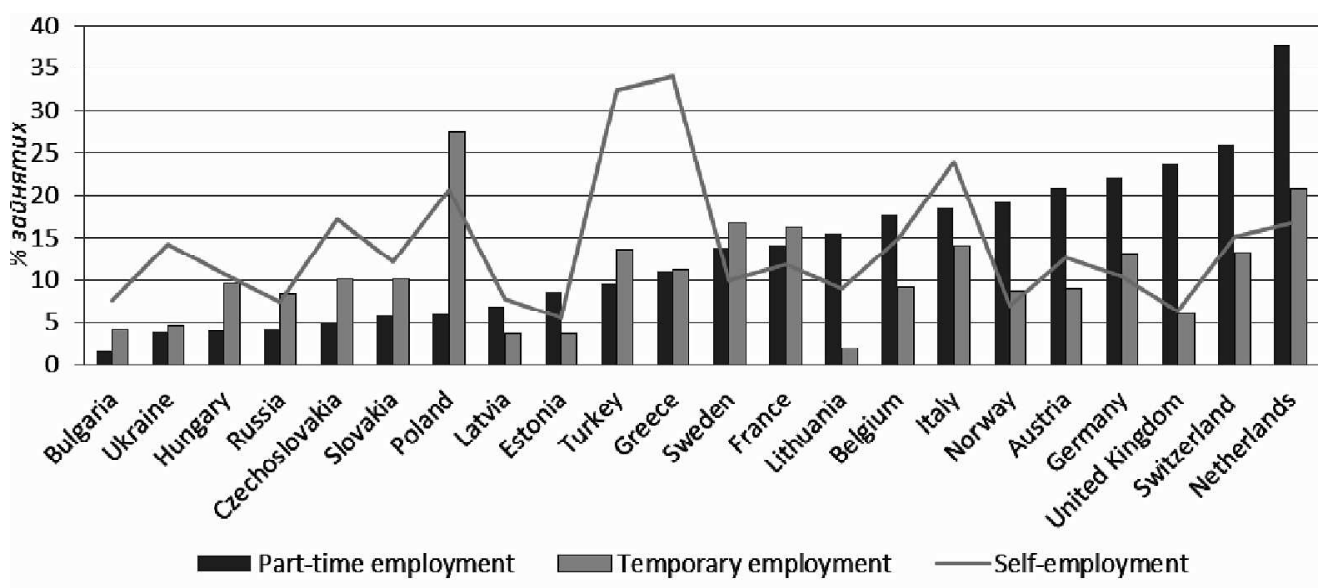

Figure 1. The share of informal employment from total non-agricultural employment employment is also large: the average regional indicator is $39.0 \%$, with a maximum of $72.2 \%$ in Peru, and the lowest in Serbia $-7.3 \%$.

In developed countries of the world with a high level of income, there are no statistics on informal employment. In some developed countries, there is a tendency to increase the proportion of people working under agreements that offer limited social protection. To designate labour agreements to be defined in accordance with the international methodological approaches outlined above, such as informal employment in developing countries, in developed countries concepts such as non-standard or atypical employment are often used.

For example, the study of the polarization of employment and quality of labour conditions conducted by the European Fund has shown that in the European labour markets there is a de-standardization of the labour relations of workers employed in low-skilled, low-paid jobs. Researchers note that part-time employment increased sharply, a more modest polarized growth in selfemployment was observed, while temporary work was dramatically reduced at the beginning of the recession, but after mid-2009, most countries reported a positive increase in such employment $[19$, p. 23].

Many, but not all, individuals working under destandardized labour agreements in developed countries are likely to be defined as informally employed, and their working conditions will not be completely identical to informal jobs in developing countries. The arrangements in question are, as a rule, called non-standard employment. This concept is associated with the concept of informal indard forms of employment from the
in countries in the world in 2016

employment, but it is not synonymous with it. Not all nonstandard employment in developed countries is informal, and not all-informal employment is non-standard. The mechanisms in question are called precarious work because they tend not to give employees a sense of security and remedies and social benefits built around standard, regular paid employment, which is determined by perpetual fulltime employment contracts. The following groups of employees refer to non-standard employees:

- self-employed, working without employees;

- temporary workers, including employees, whose employment is carried out for a certain period through specialized recruitment agencies;

- workers whose employment contract is concluded on a part-time basis.

The share of self-employed in high-income countries according to the estimates of the ILO in 2016 was $9 \%$, and in the G20 - 30.6\% of the total number of employed.

The share of temporary employment ranges from a maximum of $26.7 \%$ of hired workers in Spain, to a low of about $3 \%$ in the Baltic countries and $4 \%$ in the United States of America. Non-permanent employment exceeds $30 \%$ in 14 of the 80 countries for which the ILO provides data for 2016 , peaking at $42.2 \%$ in the Netherlands. In this country, the "national experiment" on part-time work becomes more extensive and is accompanied by a significant increase in both self-employment and temporary work. Part-time workers account for more than 20 percent of the total number of employed in 21 countries, 11 to 19 percent of underemployment is in 29 countries, below 10 percent in 15 countries (Figure 2), [9] ${ }^{1}$.

${ }^{1}$ International Labour Organization statistics http://www.ilo.org/ilostat/ 


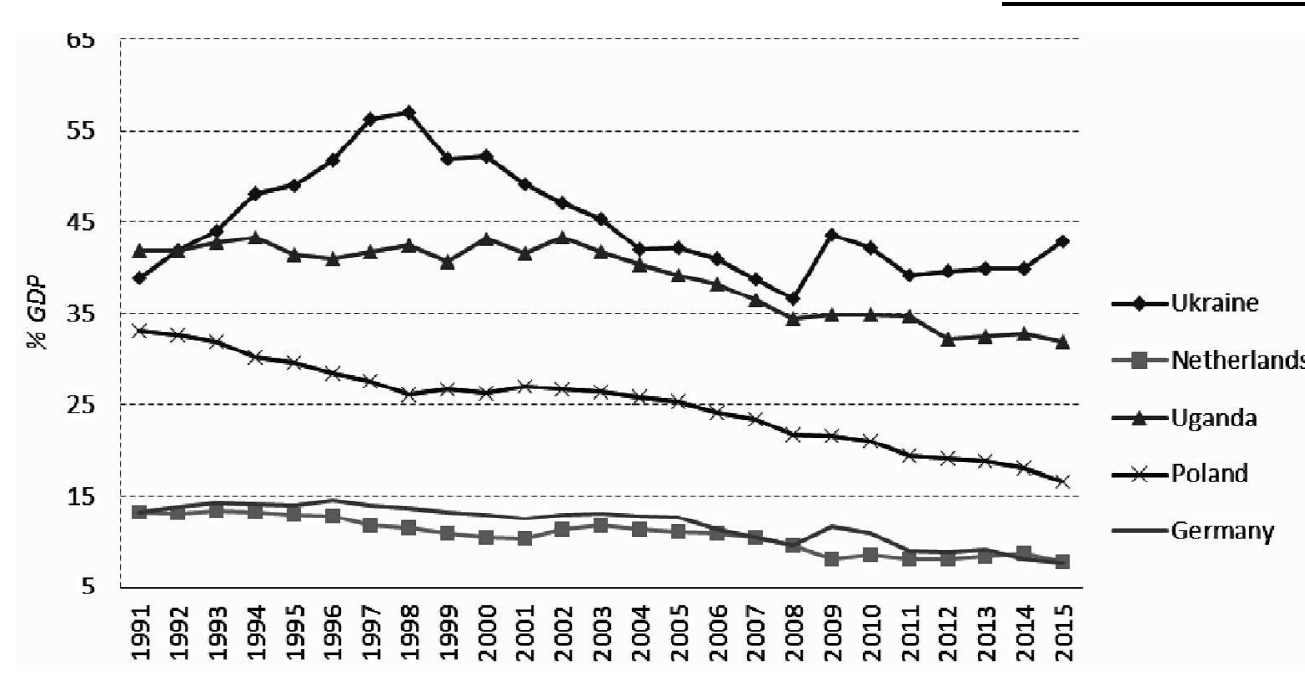

Figure 3. Size and development of the shadow economy in 1991-2015 employment provides health insurance. The criteria that characterize the sense of social security, the quality of working conditions and economic risks associated with informal and non-standard employment of the population acquire relevance.

It is also important to recognize that most official statistics on the criterion of formality of employment are collected on the de jure differences between labour agreements. De facto informality, for example, because of evasion of duties defined by labour agreements or violation of labour laws, is not reflected in official statistics. Some
Since these estimates are based on data from published sources, it is not possible to calculate the total index of precarious employment as a simple sum of constituent forms of non-standard, because one form of precarious employment can be combined with one or more others. For example, temporary workers may be employed part-time, excluding their double counting is necessary for the formation of indicators of summary statistics. In addition, in developed countries, the estimation of total precarious employment is not an exhaustive or accurate indicator of informal employment in the country, because the form of precarious work may not be reflected in statistics, that is, work with aspects of informality can be regarded as part of a permanent (standard) employment. It is also evident that not all employees with non-standard forms of employment should be classified as informally employed.

In order to obtain complete data for the analysis of all forms of informal and precarious employment, it is necessary to develop a classification of the full range of labour situations in both developed and developing countries. It would be worthwhile to justify the markers of informality, which would help to combine the definitions of informal employment with statistical indicators of non-standard employment categories used in developed countries.

These markers should determine the institutional differences in social and labour relations in different countries. For example, when comparing the size of informal employment, it is important to take into account the national institutional difference between countries with general health insurance and those where only standard temporary workers and part-time workers are covered by social protection according to labour legislation, while others are not. On the one hand, some self-employed people have the right and can afford to pay for their social protection; on the other hand, there may be people in informal employment who occupy informal jobs.

In a number of OECD countries, primarily low- and middle-income countries, unregistered employment is identified as a segment of informal employment. The shortfall in tax revenues is primarily assessed as the risk of using unregistered employment, but there is also the recognition that persons working under such conditions are denied access to social protection and can receive lower wages, especially when they receive cash in envelopes. An example of informality can also be employed by a permanent full-time employment contract for employees whose employers do not pay a portion of their social security contributions in order to reduce labour costs and pay wages "in envelopes", creating so-called "shadow" incomes.

Shadow employment in Ukraine, which manifests itself in the employment of wage earners without entering into a labour agreement and shadow wages, has been rapidly spreading in recent years, covering a significant number of workers in enterprises and organizations of the formal and informal sector of the economy. Shadow economic activity can be defined as such economic activity and income that goes beyond state regulation, taxation or supervision. For the period from $1991-2015 \mathrm{gg}$. The IMF estimated the size of the shadow sector in the structure of the Ukrainian economy at $44.8 \%$ (Figure 3 ), [19].

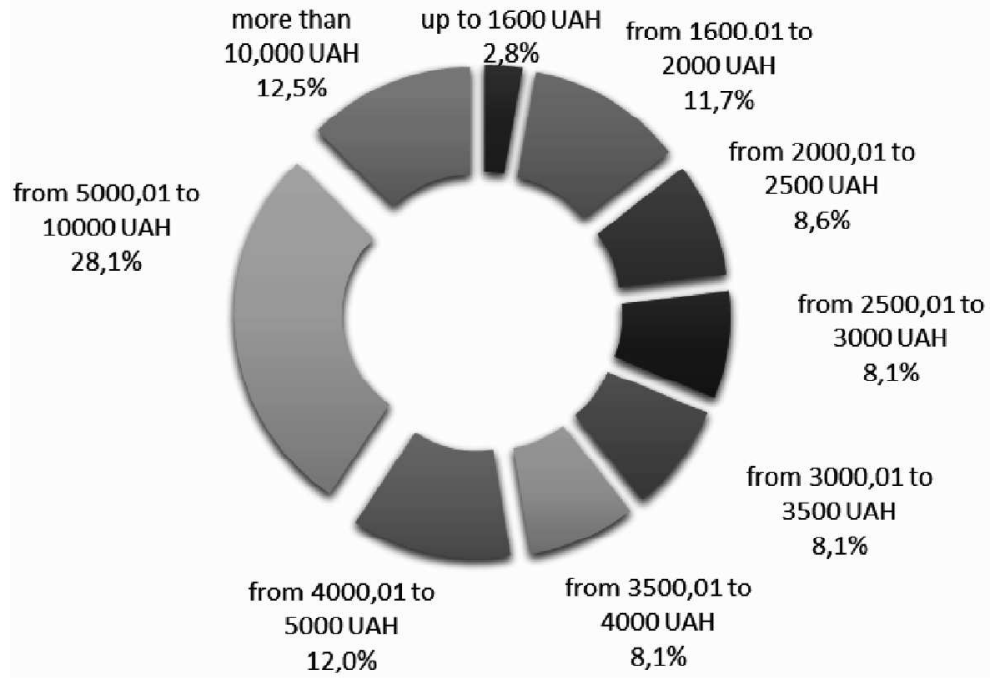

Figure 4. Distribution in Ukraine of the number of full-time employees by the amount of their salary for December 2016 


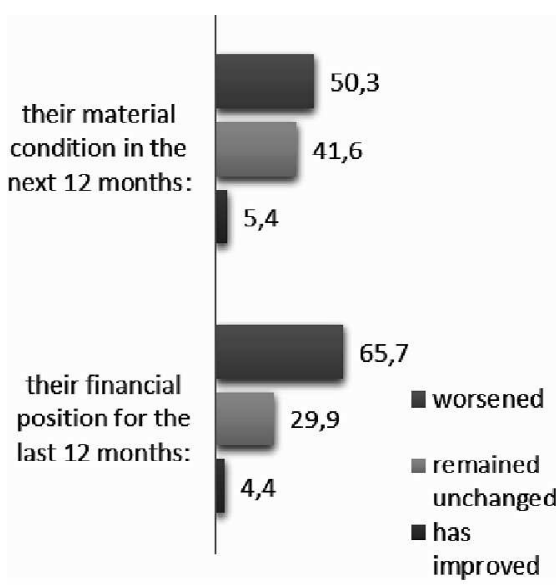

Figure 5. Self-assessment of material well-being in 2016

So, according to calculations of IMF specialists, the average size of the shadow economy of Ukraine from 1991 to 2015 is estimated at $44.8 \%$ of GDP, and in $2015-42.9 \%$. For comparison: in the Netherlands, the indicators of the shadow economy averaged $10.77 \%$ and in $20157.83 \%$ of GDP; in Germany $-11.97 \%$ and $7.75 \%$ of GDP; Poland $25.1 \%$ and $16.67 \%$; Uganda $-38.74 \%$ and $31.88 \%$ of GDP, respectively. Since 1991, when the shadow economy of Ukraine was estimated at $38.96 \%$ of GDP, the indicator continued to grow until 1998 , reaching a peak of $57 \%$. The downward trend was observed until 2008: the indicator fell to $36.65 \%$. The financial crisis caused a worsening of the situation, and during $2009-2014$, the level of the shadow economy ranged from $39.2 \%$ to $43.5 \%$. "In 2015 , the Ukrainian shadow economy was estimated at $42.9 \%$ of GDP $[19$, p. 58$]$.

To determine the scale of the shadow economy, the IMF experts used the definition of the Organization for Economic Cooperation and Development in 2016, which takes into account the tax burden and the amount of contributions to social security, labour market regulation, unemployment, the activities of unregistered enterprises, including illegal economic activity (GDP, account for criminal activity), production for own needs of households, self-employment, that is, a key element of the shadow economy and serves informal employment and economic activity in the informal economy.

Moving a large part of the employed population from the official sector of the economy to the informal sector is one of the negative phenomena of the modern labour market in Ukraine, which leads to a number of social and economic problems. The excessive use of informal employment, its close intertwining with the formal, causes the unregulated processes in the social and labour sphere. The main

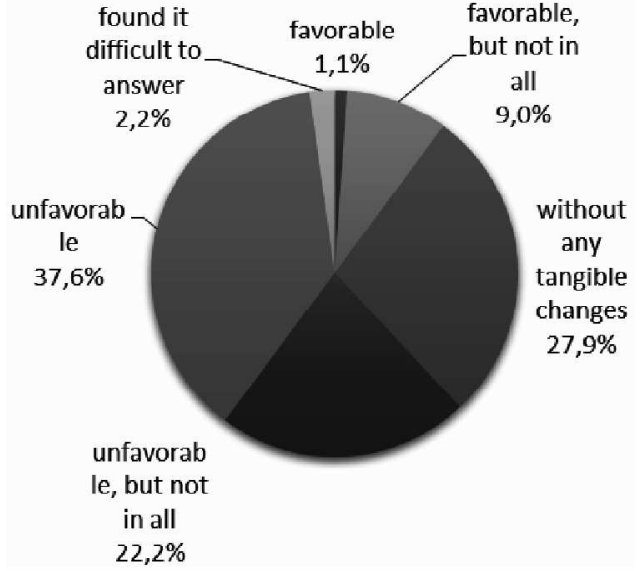

Figure 6. Households' assessment of Ukraine's economic development prospects in 2016

motivation for the spread of informal employment is the desire to receive income sufficient to meet personal needs. The official salary of a large part of those working in the formal sector does not fulfil the stimulating, motivational and reproductive functions.

The impractical decision-making in the sphere of remuneration of labour will only slow down the further resolution of problems of its shadowing, the spread of informal employment, and other social problems. One of the directions of modern social policy in this direction, according to Ukrainian economists, is the gradual introduction of a policy of social quality, which is widely used in developed countries of Europe. Ukraine at the present stage of development has a rather small macroeconomic "window of opportunity" for the formation of a society functioning on the basis of the "social quality" principle. The corresponding macroeconomic basis should be based on a high level of labour productivity and the structural proportions of the economy inherent in developed countries [1, p. 81].

In Ukraine, the share of labour payment in the total household income of the population averaged $47.7 \%$ in 2016 , and in some regions, for example, in the Transcarpathian region only $27.7 \%$. At the same time, $9.3 \%$ of households had per capita equivalent monetary incomes per month below the statutory subsistence minimum in 2016, and $63.1 \%$ - below the actual subsistence minimum [3, p. 76].

In Ukraine, according to a survey of enterprises on labour statistics, the average monthly salary of full-time employees in 2016 was 5183 UAH. This is 3.2 times higher than the subsistence minimum for able-bodied people. In December 2016,59.4\% of workers received wages below the national average, and $2.8 \%$ below the subsistence minimum (Figure 4), [10].

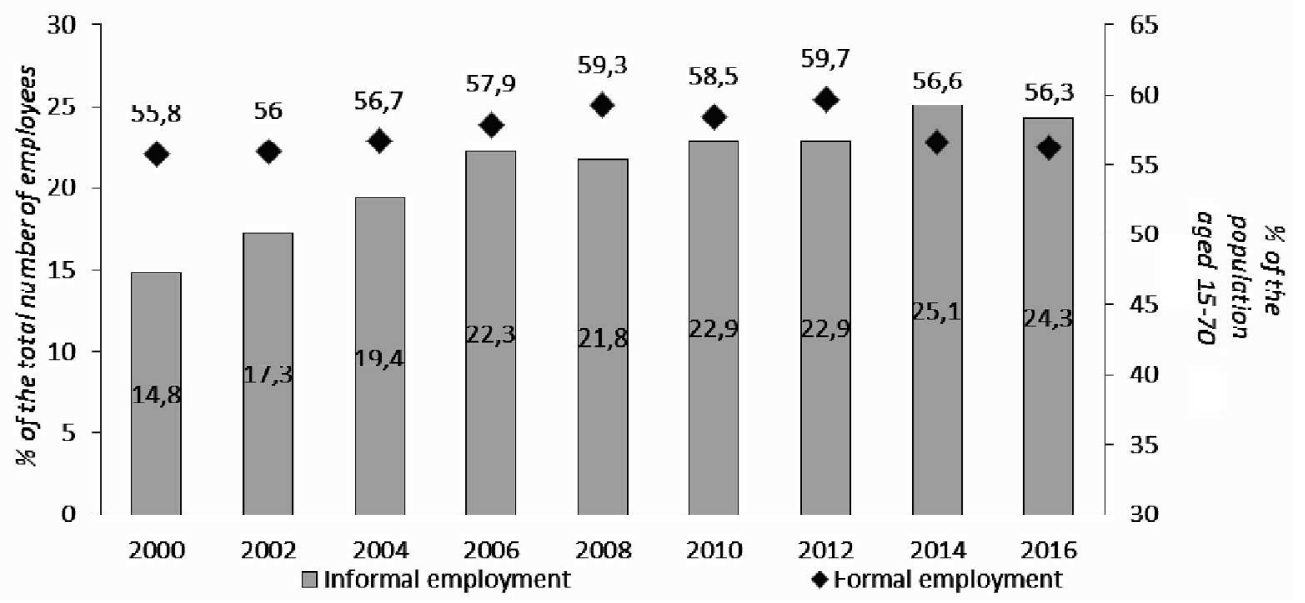

Figure 7. Dynamics of formal and informal employment in 2000-2016 
Table 3. Number of informally employed population by age group in 2016

\begin{tabular}{|c|c|c|c|c|c|c|c|c|c|}
\hline & \multicolumn{2}{|c|}{ Total } & \multirow{2}{*}{\multicolumn{7}{|c|}{$\begin{array}{l}\text { Including by age groups (years), } \\
\text { in } \% \text { of the total number of employed population of the } \\
\text { corresponding age group }\end{array}$}} \\
\hline & \multirow{2}{*}{$\begin{array}{c}\text { thousand } \\
\text { people }\end{array}$} & \multirow{2}{*}{$\begin{array}{l}\text { in } \% \text { of } \\
\text { the total } \\
\text { number of } \\
\text { employees }\end{array}$} & & & & & & & \\
\hline & & & $15-24$ & $25-29$ & $30-34$ & $35-39$ & $40-49$ & $50-59$ & $60-70$ \\
\hline $\begin{array}{l}\text { Whole } \\
\text { population }\end{array}$ & 3961,2 & 24,3 & 35,6 & 25,3 & 23,0 & 23,0 & 21,8 & 22,6 & 36,0 \\
\hline Women & 1669,0 & 21,3 & 31,5 & 21,2 & 18,5 & 20,3 & 18,7 & 20,8 & 38,5 \\
\hline Men & 2292,2 & 27,1 & 38,9 & 28,4 & 26,5 & 25,4 & 25,2 & 24,5 & 33,5 \\
\hline $\begin{array}{l}\text { Urban } \\
\text { settlements }\end{array}$ & 1891,9 & 16,9 & 25,9 & 18,8 & 17,6 & 16,7 & 15,6 & 15,0 & 14,7 \\
\hline Countryside & 2069,3 & 40,6 & 48,3 & 39,4 & 39,3 & 39,1 & 35,1 & 39,2 & 71,7 \\
\hline
\end{tabular}

development of the national economy.

In such conditions, Ukrainians use various forms of precarious work and informal employment to improve their financial situation. According to official data of the State Statistics Service of Ukraine in 2016, the number of informally employed population decreased by 342.1 thousand people compared to the previous year and amounted to 4.0 million people, or $24.3 \%$ of the total employed population $[3$, p. 76]. Comparing the trends in the development of formal and informal employment in Ukraine in recent years, it should be noted that informal employment is growing at a rapid pace (Figure 7), [12].

The employment rate of the population aged $15-70$ years in Ukraine for the period from 2000 to 2016. Grew from $55.8 \%$ to $56.3 \%$, or just 0.5 percentage points (pp). On the contrary, employment in the informal sector, on the contrary, grew actively and increased 1.6 times from $14.8 \%$ in 2000 to $24.3 \%$ in 2016 that is 9.5 percentage points rise in the level of informal employment over the period under review.

The study of the gender characteristics of informal employment showed that the employment rate in the informal sector is 2.4 percentage points higher among men than among women $(27.1 \%$ versus $21.3 \%)$. This is mainly due to the unpreparedness of the formal economy to attract workers to work with decent wage conditions, such that wages adequately fulfil their reproductive function. Income should provide a sense of security and create opportunities for sufficient material

Figure 8. Distribution of informally employed people by types of economic activity in 2016 , in \% of the entire informal workforce

The highest percentage of full-time employees who earned wages within the subsistence minimum for the ablebodied person operating in December 2016, at postal and courier companies $(11.8 \%)$, in enterprises engaged in temporary accommodation and catering $(6.8 \% \%)$ and in agriculture $(4.7 \%)$ [3, p. 76$]$. There is a tendency for households to lose self-esteem at the level of their incomes: $44.0 \%$ of households in 2016 were constantly denied necessary, except for food, in 2015 this indicator was $43.2 \%$, in $2014-41.4 \%$ of households [ 3 , p. 76]. The results of the national annual monitoring polls conducted by the Institute of Sociology of the National Academy of Sciences show that $60 \%$ of people in the village where they live are difficult to find any work [2, p. 145]. According to the material welfare of the population of Ukraine in $2014-70.7 \%$ of households attributed themselves to the poor [3, p. 77], in 2015, the share of such households was $72.3 \%$, and in $2016,74.0 \%$ of households considered themselves poor [3, p. 77].

Self-assessment The Ukrainian households have a level of their material security containing data on the subjective determination of the level of sufficiency of their incomes to meet basic needs in the past year, their expectations about the prospects for the future welfare of their families and the economy of Ukraine as a whole (Figures 5, 6), [11].

The data presented in Figures 4 and 5 show that in the last 12 months of 2016 only $4.4 \%$ of households felt their financial situation improved, more than half $(65.7 \%)$ of respondents felt that their financial situation had worsened, and in the next 12 months 2017 the situation will not improve, and even worsen $(50.3 \%$ of answers). The same pessimistic expectations for the next 12 months among the households surveyed and the development of the Ukrainian economy: $37.6 \%$ of respondents estimate the future economic conditions as unfavorable, $22.2 \%$ - partially unfavorable, $27.9 \%$ - do not expect tangible changes, and only $1,1 \%$ of households will hope for positive trends in the support for workers and their families, since men are more
likely to take on more risky, unstable, but often better-paid jobs, so they are more likely to enter the employment sector without any guarantees and dominate the informal economy. Gender differences between men and women show a difference in the distribution of informal employment by age groups. At the same time, if for women the highest level of informal labour relations is typical for persons of retirement age, then among men the most common is employment among young people aged $15-24$ years. In addition, at the working age in men with increasing age, the tendency to informal employment decreases, in women the situation almost does not change (Table 3), [12].

In the informal sector of the economy, mostly people of working age work, where their share in 2016 was $94.1 \%$. Its highest level is typical for people aged $15-24$ years $(35.6 \%)$ and aged $60-70$ years $(36 \%)$, it is these categories of the population that are most vulnerable and socially unprotected in the current economic conditions. The spread of informal employment among young people is explained by the search for earnings during education, the spread of informal employment among persons of retirement age, primarily due to low rates of pension replacement, which results in high levels of poverty among the elderly and encourages them to search for informal sources of additional means of livelihood. The desire to continue working involves forcing people older than working age to agree to informal employment, to work in positions that are not attractive to young workers. That is, in the field of employment there is the so-called ageism - discrimination of a person on an age basis. The small amount of state social transfers received by them (scholarships, pensions) and difficulties in accessing official jobs prompt youth and pensioners to seek informal sources of additional means of subsistence [8, p. 98].

The most widespread informal employment in Ukraine was among the vulnerable categories of workers - youth 
aged $15-24$ years and persons of retirement age. In the dynamics, the age structure of the informal workers undergoes certain changes. According to the State Statistics Service of Ukraine, the share of informally employed among the employed population of the ablebodied age is increasing, and among the population of the post-retirement age (60 to 70 years), on the contrary, it decreases. So, in 2016, the share of informally employed among persons aged 15 to 24 was $35.6 \%$ compared to $31.3 \%$ in 2012 . Among persons $25-$ 29 years old, respectively, $25.3 \%$ versus $20.0 \%$ and among persons $60-70$ years $-36 \%$ against $56.0 \%$ of the employed population of the corresponding age group.

In addition, the main economic activities of the informal sector of the economy after agricultural production were construction, trade, repair of cars, household products and personal items; the activities of hotels and restaurants, and this, mainly, traditionally male economic activities (Figure 8).

Among the types of economic activity, the "leader" in the spread of informal labour relations remains rural, forestry and fisheries. Despite a 1.7-fold decrease in the level of informal employment over the past five years, the value of this indicator remains quite high $-40.8 \%$. Other types of economic activity, where this type of employment is very common, is wholesale, retail trade and repair of vehicles $20.9 \%$, construction $-15.5 \%$.

An important factor in determining the choice of persons in favour of informal employment in Ukraine is the level of education. According to official statistics, the level of informal employment is declining with the growth of education in both urban and rural areas. In 2016, among the informal working population, $34.3 \%$ were persons with full secondary education, $33.2 \%$ - with vocational and $27.5 \%$ - with a full higher education.

The informal application of labour has regional features (Figure 9), [12]. In general, the territorial division of the scale of the spread of informal employment is once again more serious, first of all, its greater concentration in the regions of the agrarian orientation.

The geography of distribution shows that informal employment is most concentrated in the western regions of the country: in Ivano-Frankivsk, Chernivtsi, Rivne and Transcarpathian, its level is $53.2 \%$, respectively; $49.9 \%$; $46.5 \%$ and $35.9 \%$. The lowest figures are shown by the industrial regions of Kiev, Donetsk, Poltava, Kharkiv and Dnepropetrovsk regions. The level of informal employment in the eastern and central regions with developed infrastructure of industrial enterprises is three times lower than in the regions of the western region. At the same time, the number of employed in the formal sector (at large and medium-sized enterprises) did not increase during this period, but even decreased markedly. This is an additional indirect evidence that the costs of creating new jobs in the formal sector remain prohibitively high, and the main generator of jobs is the informal sector of the Ukrainian economy.

It should be noted that as a result of the use of informal employment and the expansion of the functioning of the informal sector of the economy, there are mixed consequences.

Informal employment can be seen as a forced form of adapting the country's population to unfavorable economic conditions. Positive in this situation is the formation of a number of socio-economic transformations: a reduction in the number of unemployed and a strain on the labour market; the possibility for a certain period of time to receive income that is higher compared to social unemployment benefits; the containment of the grow th of social tension in society; the opportunity to gain new skills, to master new professions, is an important mechanism of social, labour and professional mobility. Among the employed is an informally large number of elderly people

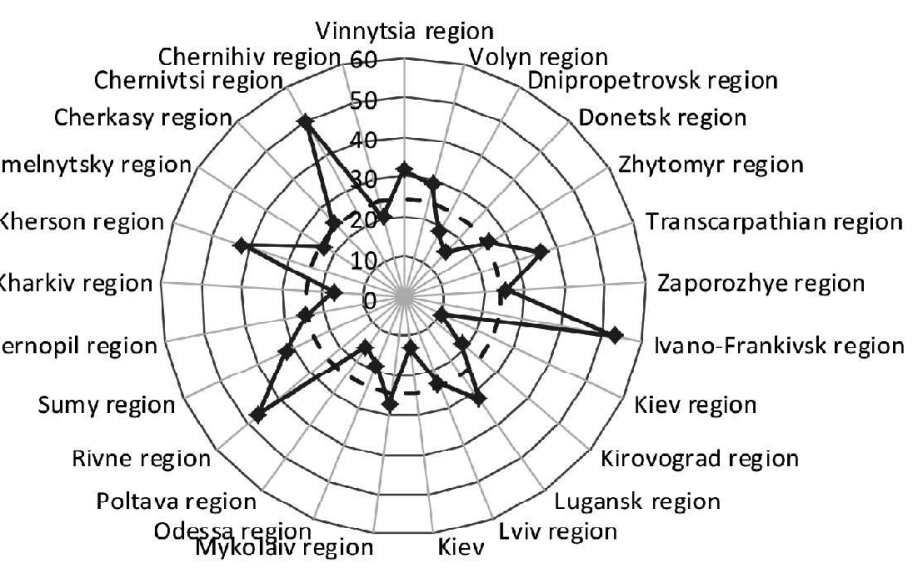

gure 9 . The share of informally employed population by regions of Ukraine in 2016 , \% of the number of employed in the region

whose pension is insignificant for sufficient material provision of individual needs, and informal employment opens up opportunities for obtaining additional income. For representatives of this age group employed, employment opportunities in enterprises in the formal sector of the economy are sharply narrowed. The deficit of the Pension Fund's resources is blocked by grants from the State Budget of Ukraine, and a change in this trend is unlikely in the near future, so the increase in pensions will be extremely slow, and informal employment will remain an important source of additional income for them.

In addition, informal employment often paves the way for small business development. Administrative barriers to entry into business and the rigidity of labour legislation do not motivate entrepreneurs to register their business. Unregistered self-employment allows individuals to start an entrepreneurial activity, develop experience, gain certain skills, form social capital, create a material "safety cushion", which guarantees a successful transition to registered formal employment.

The use of informal employment creates certain risks for the state. Thus, a shortage of tax funds by budgets of all levels and non-fulfilment of social funds due to shadowing of incomes in the informal sector of the economy leads to a deterioration in the economic situation of the population and the growth of social tensions in society as a whole. The deficit of revenues to the budget and social funds, which could be directed to the development of the socio-economic sphere and the improvement of the level and quality of life of the population.

Informal employment contributes to the growth of corruption and the shadow economy; complicates control over monetary circulation; limits the possibility of obtaining complete and reliable statistical information, negatively affects the processes of macroeconomic forecasting, the development of effective programs for the social and economic development of the state. In addition, employment in the informal sector limits the ability to implement social rights and guarantees provided by labour law; increases the risk of income instability; makes it difficult to monitor the working conditions and the quality of goods and services provided.

\section{CONCLUSIONS}

The implementation of reforms in Ukraine has the ultimate goal of building a modern European country with a developed economy capable of meeting the social needs of its citizens. However, a protracted period of complex political and economic transformations led to a crisis situation in virtually all spheres. Under such conditions, social guarantees for the realization of one of the fundamental human rights - the right to work are not fully ensured in the country. The current state of the labour market in Ukraine is characterized by 
unfavorable trends in terms of employment and inefficient use of labour. At this time, shadow employment acquired an extraordinary spread, which is accompanied by negative consequences for both the state and employees. Therefore, one of the main tasks of the state policy of Ukraine is the concentration of efforts of all branches of power on the comprehensive implementation of radical economic, administrative, managerial and organizational measures to legalize shadow employment and wages.

Reduction of informal employment in Ukraine and its legalization requires, first of all, the implementation of employment policy measures, have an anti-crisis focus. Coordination of efforts at all levels in the implementation of employment policy and the reduction of its shadowing is impossible without a scientifically based integrated national employment assistance program aimed at balancing the supply and demand for labour based on productive employment.

The employment policy should be aimed at redistribution of the labour force by sectors of the economy, territories and types of economic growth of labour productivity, with the maximum possible social support of the employed. At the same time, it should be taken into account that the initiated reforms of the economic sector and the loss of significant production potential in the ATU zone will ultimately lead to a change in the sectoral and territorial structure of the economy, and hence to a change in the structure of demand for labour. Therefore, it is important to introduce scientifically based forecasting of the scope and directions of such changes, as well as the demand structure in the labour market for the medium and long term.

The priority task for the social development of the national economy is the formation of a labour force oriented towards a highly skilled and, accordingly, highly paid model of social and labour relations. That will lead to the conclusion from the shadow of informal employment. The implementation of the employment policy using employment creation programs should be aimed at the development of small business. Supporting the development of the small business structure through the introduction of a more flexible tax system, improving the scope of lending, providing preferential terms for entrepreneurs to access legal and information and consulting services should be an important direction to reduce informal employment.

Reducing the scope of informal employment and shadowing wages in the informal sector of the economy also requires accelerating the reform of the pension system and the income sphere, which will help create incentives for the labour market to be de-institutionalized and introduce a social insurance system; streng thening employers' accountability for compliance with labour law. To do this, it is necessary to introduce changes and additions to the legislation on increasing sanctions for evading the registration of social and labour relations between the employee and the employer, pursuing a more brutal policy to strengthen the responsibility of labour market subjects for evading taxes and contributions to social funds and improving their administration. All activities - regulatory, organizational, administrative, regulatory, financial and economic, information should be coordinated and be comprehensive and systematic.

Literature:

1. Burlai T.V. Social quality policy in the context of the association agreement between Ukraine and EU / T.V. Burlai // Economics and forecasting. № 4, 2015. - P. 8195.

2. Vorona V., Shulga M. Results of the National Monitoring Surveys of 1992-2014 / Ukrainian Society: monitoring of social changes. Collection of scientific papers
Ed. Doctor of economics. K.: Institute of Sociology of NASU, T. 2, 2014 - P. 410

3. State Statistics Service of Ukraine. Self-assessment by households of Ukraine of their income level (according to the data of a sample survey of households in January 2016) / Statistical compilation //, K. - 2016. - 76 p.

4. State Statistics Service of Ukraine (2017) Costs and resources of households in Ukraine in 2016: Statistical collection. - K. - 2017. - 380 pp., P. 252.

5. State Statistics Service of Ukraine (2017). The Labour of Ukraine in 2016: Statistical Collection LLC "View Trade" August. - K. - 2017. - 234 p., P. 117.

6. State Statistics Service of Ukraine. Self-assessment by households of Ukraine of their income level (according to a sample household survey conducted in January 2017) 9 Statistical Collection. - K. - 2017. - 77 p. P. 9

7. State Statistics Service of Ukraine. Labour market of Ukraine in 2016. [Electronic resource] - Access mode: http://www.ukrstat.gov.ua/

8. Strochenkov O. Informal employment of Ukraine's population: quantitative and qualitative dimensions [Electronic resource] / O. Strochenkov // Access mode: http://commons.com.ua/neformalnazajnyatistnaselennya. - K. - 2015. - p.150

9. Statistical data of the Organization for Economic Cooperation and Development (OECD). [Electronic resource] - Access mode: http://stats.oecd.org/ and calculations by the author according to the data of the State Statistics Service of Ukraine [Electronic resource] - Access mode: http://www.ukrstat.gov.ua/.

10. Labor of Ukraine in 2016: Statistical Collection / State Statistics Service of Ukraine. - LTD. Publishing house "August Trade". - Kyiv, 2017. - 234 p., P. 117-118.

11. Self-assessment by households of Ukraine of their income level (according to a sample household survey conducted in January 2017) / Statistical Collection.// State Statistics Service of Ukraine, Kyiv, 2017. - 77 p. - P. 12.

12. State Statistics Service of Ukraine [Electronic resource]. - Access mode: http://www.ukrstat.gov.ua/

13. European Communities (1993) System of National Accounts 1993/ Prepared under the auspices of the InterSecretariat Working Group on National Accounts: Commission of the European Communities - Eurostat, International Monetary Fund, Organisation for Economic Co-operation and Development, United Nations, World Bank. - Brussels/Luxembourg, New York, Paris, Washington, D.C. -838 p., P. 135

14. Hurley J., Fernandez-Macias E. and Storrie D. (2013) Employment polarisation and job quality in the crisis: European Jobs Monitor 2013/ Eurofound. - Dublin. 83 p.

15. ILO (1993) Reports and related documents of the 15 th International Conference of Labour Statisticians. Geneva, $19-28$ January. - 62 p.

16. ILO (2003) Final report of the 17 th International Conference of Labour Statisticians / International Labour Office. Geneva, 24 November - 3 December 2003. 156 p. P. $10-16$.

17. ILO (2004) Hussmanns Ralf Measuring the informal economy: From employment in the informal sector to informal employment / Working Paper No. 53 // Policy Integration Department Bureau of Statistics International Labour Office. - Geneva. 42 p.

18. ILO (2018) Statistics of the International Labour Organization http://www.ilo.org/ilostat/.

19. IMF (2018) Medina L. and Schneider F. Shadow Economies Around the World: What Did We Learn Over the Last 20 Years? / IMF Working Paper // Department of Economics, Johannes Kepler University of Linz. - 76p. P. $61-75$.

20. Final report of the 17 th International Conference of Labour Statisticians / International Labour Office. Geneva, 24 November - 3 December 2003. - 156 p. - P. 15 .

Стаття надійшла до редакиіï 10.03.2020 p. 